\title{
HUBUNGAN RISK PROFILE DENGAN KINERJA KEUANGAN BANK PANIN DUBAI SYARIAH 2016-2020
}

\author{
Firdaus ${ }^{1}$, Imam Fakruddin' ${ }^{2}$, Jamiah ${ }^{3}$, Fitri Saphira ${ }^{4}$, Sahyu Safhira ${ }^{5}$, Saifullah ${ }^{6}$ \\ Corresponding Authors: Sekolah Tinggi Agama Islam Negeri Bengkalis \\ Email: rinaastuti23072018@gmail.com
}

Copyright (C) 2022

\section{water}

\begin{abstract}
This research was conducted to examine the correlate of Risk Profile (Non Performing Financing (NPF) and Financing Deposite Ratio (FDR) to Return on Asset (ROA).This research uses quantitatif method. The population of this research is the financial report Panin Dubai Syariah bank period 2016 through 2020. Sensus sampling method were used as samples determining, whre all the population is sampled. Analysis method with correlation pearson. The result of the research is Non Performing Financing/NPF has negative correlated and significant with Return on Asset (ROA) and Financing Deposite Ratio (FDR) has negative correlated and significant with Return on Asset (ROA). The implication of this research is that the poor NPF and FDR of Panin Dubai Syariah Bank have an impact on the company's ability to generate profits. High NPF and FDR lead to a decrease in ROA. For this reason, Panin Dubai Syariah Bank needs to maintain NPF and FDR in accordance with the minimum standards set by Bank Indonesia.
\end{abstract}

Keywords: Bank Panin Dubai Syariah, ROA, NPF, FDR

Abstrak: Penelitian ini bertujuan untuk mengukur hubungan risk profile (Non Performing Financing/NPF dan Financing Deposite Ratio/FDR) dengan Return on Asset (ROA). Penelitian ini merupakan penelitian kuantitatif. Populasi dalam penelitian ini adalah laporan keuangan bank Panin Dubai Syariah periode 2016 sampai 2020. Teknik sampling yang digunakan adalah sensus, dimana semua populasi dijadikan sampel. Teknik analisis data yang digunakan adalah korelasi pearson. Hasil penelitian menunjukkan bahwa Non Performing Financing (NPF) dan Financing Deposite Ratio (FDR) memiliki hubungan negatif dan signifikan dengan Return on Asset (ROA). Implikasi dalam penelitian ini adalah kurang baiknya NPF dan FDR dari Bank Panin Dubai Syariah berdampak terhadap kemampuan perusahaan dalam menghasilkan labanya. NPF dan FDR yang tinggi mengakibatkan turunnya ROA. Untuk itu, bank Panin Dubai Syariah perlu menjaga NPF dan FDR yang sesuai standar minimal yang telah ditetapkan oleh Bank Indonesia.

Kata Kunci: Bank Panin Dubai Syariah, ROA, NPF, FDR 


\section{PENDAHULUAN}

Perkembangan perbankan Islam merupakan fenomena yang menarik bagi kalangan akademisi maupun praktisi dalam dua puluh tahun terakhir. International Monetary Fund (IMF) juga Melakukan kajian-kajian atas praktik perbankan Islam sebagai alternatif sistem keuangan international yang memberikan peluang besar bagi industri keuangan dunia. Upaya penyempurnaan sistem keuangan internasional yang belakangan dirasakan banyak sekali mengalami goncangan dan ketidakstabilan yang menyebabkan krisis dan keterpurukan ekonomi akibat lebih dominannya sektor financial dibanding sektor riil.

Perbankan syariah mengharuskan produk dan jasa keuangan yang ditawarkan harus sesuai dengan syariah atau hukum Islam. Dengan mengembangkan aplikasi syariah menjadi alternatif lain dengan bank konvensional, dimana sekarang produk bank Islam mengakomodasi kebutuhan jangka pendek dan jangka panjang dari keinginan konsumen.

Mengingat pentingnya peran perbankan dalam kegiatan bisnis, Bank Indonesia telah mengatur peraturan dengan tujuan agar seluruh perusahaan yang berada dalam sub sektor bank telah beroperasi dengan baik, yaitu (SEBI No. 13/24/DPNP, 2011) yang menyatakan bahwa untuk menilai kesehatan perusahaan subsektor bank terdapat empat faktor yaitu: profil risiko, good corporate governance, pendapatan dan permodalan

Risiko adalah segala sesuatu yang dampaknya merugikan perusahaan, atau hasil yang terjadi tidak sesuai dengan yang diharapkan (Hanafi, 2014).

Kinerja keuangan merupakan gambaran dari pencapaian keberhasilan perusahaan dapat diartikan sebagai hasil yang telah dicapai atas berbagai aktivitas yang telah dilakukan. Indikator kinerja suatu perusahaan salah satunya adalah profitabilitas (Niode, 2016). Salah satu rasio profitabilitas yakni ROA (Return on Assets).

ROA merupakan salah satu rasio rentabilitas/profitabilitas. Rasio ini menunjukkan bagaimana pengembalian atas aktiva, atau seberapa besar laba yang diperoleh perusahaan dengan memanfaatkan aktiva yang dimiliki perusahaan (Kasmir, 2018).

Dengan mengetahui ROA, kita dapat mengetahui apakah perusahaan telah efisien dalam menggunakan aktivanya dalam menghasilkan laba dengan menggunakan asetnya. Apabila ROA suatu bank besar, maka besar pula keuntungan yang didapat oleh bank.

Bank Panin Dubai Syariah Tbk atau Panin Dubai Syariah Bank (Perseroan) didirikan sejak tahun 1972. Sehubungan dengan masuknya Dubai Islamic Bank PJSC sebagai salah satu Pemegang Saham.

Keuangan sebuah perusahaan menjadi tolak ukur bagaiamana suatu perusahaan dapat bertahan kedepan 
nya. Rasio yang digunakan untuk mengukur kinerja salah satunya adalah ROA Berikut merupakan data ROA (Return on Asset), pada Bank Panin Dubai Syariah Periode 2016-2020:

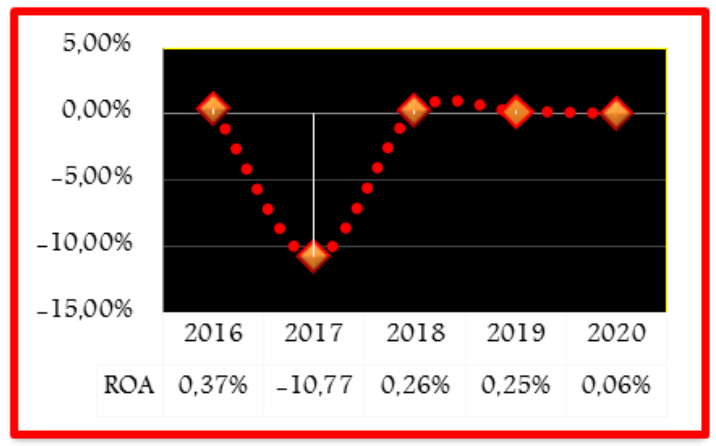

Gambar 1.

Pergerakan ROA Bank Panin Dubai Syariah Periode 2016-2020

Sumber: Annual Report Bank Panin Dubai Syariah (2021)

Dari tabel Statistik diatas dapat dilihat bahwa ROA pada Bank Panin Dubai bergerak secara fluktuatif. Terjadi penurunan yang sangat signifikan ditahun 2017. Namun sedikit membaik ditahun 2018 dan 2019, masuk kedalam kategori cukup sehat. Trend positif di 2018 dan 2019 tidak bisa bertahan di tahun 2020, dimana kembali turun cukup signifikan sehingga ROA bank Panin Dubai Syariah kembali masuk kategori kurang sehat.

Hal ini dipengaruhi oleh berbagai faktor, diantaranya faktor internal yang mempengaruhi profitabilitas bank bisa diukur dengan menggunakan rasiorasio keuangannya, rasio-rasio yang mempengaruhi ROA adalah Non Performing Finance (NPF), dan Financing to Deposit Ratio (FDR). Non Performing Financing (NPF) adalah rasio keuangan yang menunjukkan risiko pembiayaan yang dihadapi bank akibat pemberian pembiayaan dan investasi dana bank pada portofolio yang berbeda.

Penelitian relevan yang dilakukan (Niode \& Chabachid, 2016) dan (Fachri, 2021) menunjukkan bahwa NPF berpengaruh negatif dan signifikan terhadap ROA. Sementara itu penelitian yang dilakukan (Wibisono \& Wahyuni, 2017) menunjukkan bahwa NPF tidak siginifikan terhadap ROA. Adanya perbedaan hasil penelitian ini, maka perlu dilakukan penelitian lanjutan mengenai hubungan NPF terhadap ROA.

Financing to Deposit Ratio (FDR) adalah perbandingan antara pembiayaan yang diberikan oleh bank dengan dana pihak ketiga yang berhasil dihimpun oleh bank. Semakin rendah FDR menunjukkan kurangnya efektifitas bank dalam menyalurkan kredit.

Penelitian yang dilakukan oleh (Niode\&Chabachid, 2016), (Wibisono \& Wahyuni, 2017) menunjukkan bahwa FDR berpengaruh positif dan signifikan terhadap ROA. Sementara itu penelitian yang dilakukan oleh (Fachri, 2021) menunjukkan hasil yang berbeda, FDR tidak signifikan terhadap ROA. Adanya research gap dari beberapa penelitian ini, maka perlu dilakaukan penelitian lebih lanjut tentang hubungan FDR dengan ROA.

Risiko pembiayaan ini dapat terjadi akibat kegagalan atau ketidak mampuan nasabah dalam mengembali kan jumlah pinjaman yang diterima dari bank beserta bagi hasilnya sesuai 
dengan jangka waktu yang telah ditentukan (Kuncoro, 2011).

\section{KAJIAN TEORI}

\section{Profil risiko}

Merupakan sistem nilai untuk mengetahui risiko inheren dan juga kualitas dari manajemen risiko dalam operasional perusahaan sub sektor bank (SEBI No. 13/24/DPNP, 2011).

1. Risiko Inheren Yaitu risiko yang berkaitan erat dengan risiko perbankan. Baik itu yang dapat dianalisis dengan menggunakan angka dan juga tidak, serta berpotensi mengganggu kinerja Keungan perbankan. Karakteristik dari risiko inheren ini yaitu dipengaruhi oleh faktor internal dan eksternal, seperti strategi, karakteristik, Produk dan aktivitas, domisili, dan yang terakhir adalah kondisi ekonomi.

2. Kualitas Penerapan Manajemen Risiko Dengan tujuan yaitu untuk mengetahui tingkat kualitas dari setiap manajemen resiko perusahaan sub sektor bank, penilaian ini mencakup seluruh risiko yang wajib diterapkan sesuai arahan dari bank indonesia. Penilaian yang dimaksud meliputi:

a. pengelolaan risiko,

b. kerangka manajemen risiko,

c. proses penerapan manajemen risiko, dan yang terakhir yaitu,

d. sistem untuk mengendalikan risiko. Keempat nilai ini sangat memperhatikan karakteristik suatu perusahaan sub sektor bank.

\section{Kinerja Keuangan Bank}

Kinerja adalah suatu hasil atau tingkatan mengenai keberhasilan seseorang secara keseluruhan melakukan tugas dibandingkan dengan berbagai kemungkinan, seperti standar hasil kerja, terget atau sasaran atau kreteria yang telah ditentukan terlebih dahulu dan telah disepakati bersama. (Fahmi, 2015).

Kinerja keuangan bank merupakan gambaran prestasi yang dicapai oleh bank dalam operasionalnya, baik menyangkut aspek keuangan, pemasaran, penghimpunan atau penyaluran dana, teknologi maupun sumberdaya manusia itu sendiri. Berkaitan dengan analisis kinerja keuangan bank mengandung beberapa tujuan antara lain sebagai berikut (Jumingan, 2006):

a. Untuk mengetahui keberhasilan pengelolaan keuangan bank terutama kondisi likuiditas, kecukupan modal dan profitabilitas yang dicapai dalam tahun berjalan maupun tahun sebelumnya.

b. Untuk mengetahui kemampuan bank dalam memberdayakan semuahn aset yang dimiliki dalam menghasilkan profit/laba secara efektif dan efisien.

c. Untuk meningkatkan peran bank sebagai lembaga intermediasi antara pihak-pihak yang kekurangan dana. 


\section{Rasio Keuangan Bank}

Analisis Perbandingan (Ratio Analysis) merupakan Suatu teknik atau peralatan untuk mengevaluasi kondisi financial dan kinerja sebuah organisasi perusahaan (Darmawi, 2011: 201)

Untuk mengetahui keadaan keuangan suatu bank, maka dapat dilihat dari laporan keuangan yang disajikan oleh suatu bank secara berkala. Laporan ini juga sekaligus menggambarkan kinerja bank selama periode tersebut. Laporan ini sangat berguna terutama bagi pemilik, manajemen, pemerintah, dan masyarakat sebagai nasabah bank, guna mengetahui kondisi bank tersebut. Setiap laporan yang disajikan haruslah dibuat sesuai dengan standar yang telah ditetapkan (Kasmir, 2015, p. 310).

Dalam penelitian ini tidak semua rasio yang telah disebutkan sebelumnya akan dipergunakan untuk melakukan analisis. Dalam penelitian ini rasio yang digunakan adalah rasio Return on Asset (ROA), Non Performing Financing (NPF), Financing to Deposit Ratio (FDR).

Adapun rasio keuangan yang digunakan tersebut adalah sebagai berikut:

\section{Return on Asset (ROA)}

Return on Asset (ROA) disebut juga kemampuan laba atas asset/mengukur tingkat laba terhadap aset yang digunakan dalam menghasilkan laba tersebut. Return on Asset (ROA) dapat juga diartikan mengukur kemampuan perusahaan dalam mendayagunakan aset untuk memperoleh laba (Prihadi, n.d., p. 68). Rasio ini dirumuskan sebagai berikut:

$$
\text { ROA }=\frac{\text { Laba Bersih }}{\text { Total Aktiva }} \times 100 \%
$$

Return on Asset (ROA) adalah rasio keuangan yang digunakan untuk mengukur kemampuan manajemen bank dalam memperoleh keuntungan (profit) secara keseluruhan, semakin besar ROA suatu bank, maka semakin besar pula tingkat keuntungan yang dicapai bank tersebut dan semakin baik pula posisi bank tersebut dari segi penggunaan aset. Standar terbaik ROA menurut Syarat Edaran Bank Indonesia adalah sebesar $1,5 \%$.

Tabel 1

Kriteria Penilian Peringkat ROA

\begin{tabular}{||c||c||c||}
\hline \hline Peringkat & Keterangan & Kriteria \\
\hline \hline $\mathbf{1}$ & Sangat Sehat & ROA $>1,5 \%$ \\
\hline $\mathbf{2}$ & Sehat & $\begin{array}{c}1,25 \%<\mathrm{ROA} \leq \\
1,5 \%\end{array}$ \\
\hline $\mathbf{3}$ & Cukup Sehat & $\begin{array}{c}0,5 \%<\mathrm{ROA} \leq \\
1,25 \%\end{array}$ \\
\hline $\mathbf{4}$ & Kurang Sehat & $0 \%<\mathrm{ROA} \leq$ \\
& & $0,5 \%$ \\
\hline $\mathbf{5}$ & Tidak Sehat & ROA $\leq 0 \%$ \\
\hline
\end{tabular}

Sumber: Surat Edaran Bank Indonesia (2021)

\section{Non Performing Financing(NPF)}

Non Performing Financing (NPF) adalah kredit yang kategori kolektibi litasnya diluar kolektibilitas kredit lancar dan kredit dalam perhatian khusus. Berarti kredit bermasalah mencakup kredit kurang lancar, diragukan dan macet (Ericso, 2007, p. 95). Non Performing Loan (NPL) diperuntukkan bagi bank umum sedangkan Non Performing Financing (NPF) untuk bank syariah 
(Wangsawidjaja, 2020, p. 344). Rasio ini dirumuskan sebagai berikut:

$$
\text { NPF }=\frac{\text { Total Kredit Bermasalah }}{\text { Total Kredit }} \times 100 \%
$$

Kredit yang dimiliki oleh bank dikatakan sebagai kredit bermasalah apabila memnuhi kriteria kurang lancar, diragukan, dan macet. Rasio Non Performiing Loan (NPL) menunjukkan kualitas kredit yang diberikan oleh bank. Semakin tinggi Non Performiing Loan (NPL) menunjukkan semakin besar juga kredit bermasalah pada kategori kurang lancar, diragukan, dan macet yang dimiliki oleh bank. Hal tersebut, menjelaskan bahwa Non Performiing Loan (NPL) merupakan signal negatif atas kinerja yang dimiliki oleh bank. Semakin besar nilai Non Performiing Loan (NPL) menandakan semakin jelek kualitass kredit yang dimiliki oleh bank. Berdasarkan peraturan Surat Edaran Bank Indonesia menetapkan bahwa batas Non Performiing Loan (NPL) yang harus dimiliki oleh bank sebesar 5\% (Akbar, 2019).

Tabel 2

Kreteria Penilaian Peringkat NPF

\begin{tabular}{|c||c|c||}
\hline Peringkat & Keterangan & Kriteria \\
\hline $\mathbf{1}$ & Sangat Sehat & $<5 \%$ \\
$\mathbf{2}$ & Sehat & $\begin{array}{c}2 \% \leq \mathrm{NPL} / \mathrm{NPF} \\
<5 \%\end{array}$ \\
\hline $\mathbf{3}$ & Cukup Sehat & $\begin{array}{c}5 \% \leq \mathrm{NPL} / \mathrm{NPF} \\
<8 \%\end{array}$ \\
\hline $\mathbf{4}$ & Kurang Sehat & $\begin{array}{c}8 \% \leq \mathrm{NPL} / \mathrm{NPF} \\
<12 \%\end{array}$ \\
& & NPL/NPF $>8 \%$ \\
\hline $\mathbf{5}$ & \multicolumn{3}{|c|}{ Tidak Sehat } & . \\
\hline \multicolumn{2}{|c|}{ Sumber: Surat Edaran Bank Indonesia $(2021)$}
\end{tabular}

\section{Financing to Deposit Ratio (FDR)}

Financing to deposit ratio (FDR) adalah istilah untuk perbankan syariah yang berfungsi sebagai intermediasi bank syariah. Istilah FDR digunakan karena dalam perbankan syariah tidak dikenal istilah utang (loan). Bank syariah hanya mengenal financing atau pembiayaan. Financing to Deposit Ratio (FDR) merupakan rasio yang digunakan untuk mengukur likuiditas suatu bank dalam membayar kembali penarikan dana yang dilakukan deposan dengan mengandalkan pembiayaan yang diberikan sebagai sumber likuiditasnya, yaitu dengan cara membagi jumlah pembiayaan yang diberikan oleh bank terhadap Dana Pihak Ketiga (DPK).

Dalam jurnal ilmiah mengenai Financing to Deposit Ratio yang dianalisa oleh Didin Rasyidin Wahyu, semakin tinggi Financing to Deposit Ratio (FDR) maka semakin tinggi dana yang disalurkan ke Dana Pihak Ketiga (DPK) tetapi semakin rendah kemampuan likuiditasnya. Dengan penyaluran Dana Pihak Ketiga (DPK) yang besar maka pendapatan bank Return on Asset (ROA) akan semakin meningkat, sehingga Financing to Deposit Ratio (FDR) berpengaruh positif terhadap Return on Asset (ROA).

Semakin besar dana yang diterima bank, maka semakin tinggi pula resiko yang ditanggung. Resiko seperti non performing finance dan credit risk dapat membuat bank kesulitan dalam mengembalikan dana yang dititipkan nasabah. Penyebabnya antara lain 
kredit gagal atau kredit bermasalah. Sebaliknya, angka FDR yang tinggi menunjukkan bahwa sebuah bank likuid. Meskipun artinya bank tersebut memiliki banyak dana menganggur (idle fund). Jika dana tersebut tidak dimanfaatkan, maka bank dapat kehilangan kesempatan untuk mendapatkan penerimaan dalam jumlah besar melalui bunga pinjaman. Jika hal ini tidak dilakukan, maka bank tersebut tidak menjalan peran sebagai financial intermediary.

Hasil penghitungan FDR dapat digunakan sebagai indikator untuk mengukur kemampuan sebuah bank dalam membayar kembali penarikan yang dilakukan nasabah dengan menggunakan kredit sebagai sumber likuiditas. Berikut ini adalah kriteria FDR yang ditetapkan oleh Bank Indonesia:

Tabel 3

Kreteria Penilaian Peringkat FDR

\begin{tabular}{|c||l|l|}
\hline Peringkat & \multicolumn{1}{|c|}{ Keterangan } & Kriteria \\
\hline \hline $\mathbf{1}$ & $\begin{array}{l}\text { Peringkat 1 50\% } \\
<\text { FDR } \leq 75 \%\end{array}$ & $\begin{array}{l}\text { Sangat } \\
\text { Sehat }\end{array}$ \\
\hline $\mathbf{2}$ & $\begin{array}{l}\text { Peringkat 2 75\% } \\
<\text { FDR } \leq 85 \%\end{array}$ & Sehat \\
\hline $\mathbf{3}$ & $\begin{array}{l}\text { Peringkat 3 85\% } \\
<\text { FDR } \leq 100 \%\end{array}$ & $\begin{array}{l}\text { Cukup } \\
\text { sehat }\end{array}$ \\
\hline $\mathbf{4}$ & $\begin{array}{l}\text { Peringkat 4 100\% } \\
<\text { FDR } \leq 120 \%\end{array}$ & $\begin{array}{l}\text { Kurang } \\
\text { Sehat }\end{array}$ \\
\hline $\mathbf{5}$ & $\begin{array}{l}\text { Peringkat 5 FDR }> \\
\text { Tidak Sehat }\end{array}$ & Tide \\
\hline
\end{tabular}

Sumber: Surat Edaran Bank Indonesia (2021)

\section{METODE PENELITIAN}

Jenis Penelitian

Penelitian kuantitatif dapat diartikan sebagai metode penelitian yang berlandaskan pada filsafat Positivisme, digunkan untuk meneliti pada populasi atau sampel tertentu, pengumpulan data menggunakan instrumen penelitian, analisis data bersifat kuanttitatif atau statistik, dengan tujuan untuk menguji hipotesis yang telah di tetapkan. Jenis penelitian yang digunakan dalam penelitian ini adalah penelitian kuantitatif.

Dalam penelitian ini, peneliti mengumpulkan data dengan menggunakan instrument yang bersifat mengukur kemudian data yang diperoleh dianalisis dengan statistik (Spomo, 2002, p. 141).

\section{Populasi dan Sampel Penelitian Populasi Penelitian}

Populasi merupakan kelompok atau kumpulan individu-individu atau obyek penelitian yang memiliki standar-standar tertentu dari ciri-ciri yang telah ditetapkan sebelumnya. Berdasarkan kualitas dan ciri tersebut, maka populasi dapat dipahami sebagai sekelompok individu atau objek pengamatan yang minimal memiliki satu persamaan karakteristik (Firdaus, 2021, p. 74).

Populasi dalam penelitian ini adalah Laporan Keuangan Bank Panin Dubai Syariah periode 2016-2020.

\section{Sampel Penelitian}

Sampel sebagian dari populasi yang memiliki karakteristik relatif sama dan dianggap dapat mewakili populasi (Sugiyono, 2016, p. 120). Teknik sampling dalam penelitian ini menggunakan sensus. Dimana, semua anggota populasi dijadikan sampel dalam penelitian ini. 


\section{Teknik Analisis Data}

\section{Metode Analisis Deskriptif}

Statistik deskriptif adalah statistik yang digunakan untuk menganalisa data dengancara mendeskripsikan atau menggambarkan data yang telah terkumpul sebagaimana adanya tanpa bermaksud membuat kesimpulan yang berlaku untuk umum atau generalisasi

Metode ini merupakan suatu metode analisis dimana data yang dikumpulkan mula-mula disusun, diklasifikasikan dan dianalisis sehingga akan memberikan gambaran yang jelas mengenai masalah yang sedang diteliti.

\section{Analisis Korelasi Pearson}

Analisis korelasi Pearson ditujukan untuk pasangan pengamatan data rasio yang menunjukkan hubungan yang linier (Situmorang, dkk, 2008). Korelasi ini sering juga disebut Korelasi Product Moment. Menghitung nilai koefisien korelasi Pearson dapat dilakukan dengan menggunakan rumus:

$$
r_{x y^{2}}=\frac{\left[N \sum X Y-\left(\sum X\right)\left(\sum Y\right)\right]^{2}}{\left[\sum_{X} 2-\left(\sum_{X}\right) 2\right]\left[N \sum_{Y} 2-\left(\sum_{Y}\right) 2\right]}
$$

Koefisien korelasi besarnya antara -1 sampai +1 . Tanda positif dan negatif menunjukkan arti atau arah dari hubungan koefisien korelasi tersebut. Korelasi positif nilainya berada diantara 0 sampai +1 , nilai menjelaskan bahwa apabila ada suatu variabel naik maka akan menyebabkan kenaikan pada variabel yang lainnya, dan sebaliknya.

Korelasi negatif nilainya berada antara -1 sampai 0, nilai tersebut menjelaskan bahwa apabila suatu variabel naik maka variabel lainnya akan turun, dan sebaliknya. Untuk dapat memberikan interpretasi terdapat kuat atau lemahnya hubungan antar variabel, maka dapat digunakan adalah:

Tabel 4

Pedoman untuk Memberikan Interpretasi Koefisien Korelasi

\begin{tabular}{||l|l|}
\hline Interval Koefisien & \multicolumn{1}{|c|}{$\begin{array}{c}\text { Tingkat } \\
\text { Hubungan }\end{array}$} \\
\hline $0,00-0,199$ & Sangat Rendah \\
\hline $0,20-0,399$ & Rendah \\
\hline $0,40-0,599$ & Sedang \\
\hline $0,60-0,799$ & Kuat \\
\hline $0,80-1,000$ & Sangat Kuat \\
\hline
\end{tabular}

Sumber: Sugiyono (2016)

Pengujian Hipotesis:

Uji signifikansi korelasi Pearson digunakan untuk menunjukkan apakah secara individual variabel bebas (X) mempunyai hubungan yang signifikan atau tidak terhadap variabel terikat (Y).

\section{HASIL DAN PEMBAHASAN}

\section{Deskriptif Variabel Penelitian}

Deskriptif Variabel Non Performing Financing (NPF)

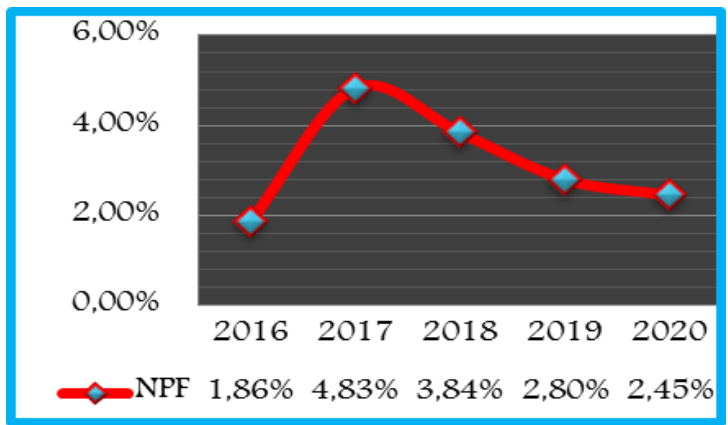

Gambar 2. NPF Bank Panin Dubai Syariah Tahun 2016-2020

Sumber: Annual Report Panin Dubai Syariah (2021)

82 | Hubungan Risk Profile dengan Kinerja Keuangan Bank Panin..... 
Dilihat dari garfik diatas rasio Non Performing Financing (NPF) berfluktuatif dari tahun 2016-2020. Pada tahun 2016 angka NPF mencapai 1.86\% kemudian pada tahun 2017 naik menjadi $4.83 \%$ pada tahun 2018 mengalami penurunan $3.84 \%$ kemudian pada tahun 2019 juga mengalami penurunan sehingga angka mencapai paada $2.80 \%$ dan pada tahun 2020 kembali mengalami penurunan di angka $2.45 \%$. Hal ini menunjukan rasio Non Performing Financing (NPF) dalam keadaan sehat karena semakin tinggi rasio ini maka akan semakin buruk kualitas kredit bank menyebabkan jumlah kredit bermasalah semakin besar.

\section{Deskriptif Variabel Financing Deposit Ratio (FDR)}

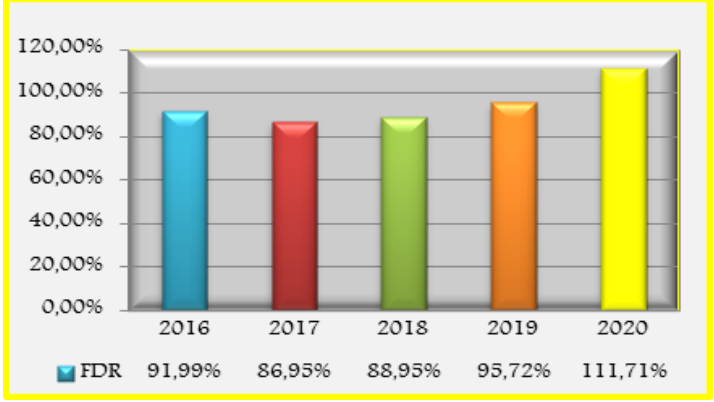

Gambar 3. FDR Bank Panin Dubai Syariah Tahun 2016-2020(Dalam Persen \%) Sumber: Annual Report Panin Dubai Syariah (2021)

Dilihat dari grafik diatas Financing Deposit Ratio (FDR) bergerak fluktuatif dari tahun 2016-2020. Pada tahun 2016 angka FDR mencapai 91.99\% kemudian pada tahun 2017 mengalami penurunan menjadi $86.95 \%$ dan pada tahun 2018 mengalami kenaikan menjadi $88.95 \%$ pada tahun 2019 mengalami kenaikan sebesar
95.72\% dan pada tahun 2020 mengalami kenaikan kembali menjadi 111.71\%. dilihat dari uraian apabila angka FDR terlalu tinggi, maka itu juga tidak baik untuk bank.

\section{Deskriptif Variabel Return on Assets} (ROA)

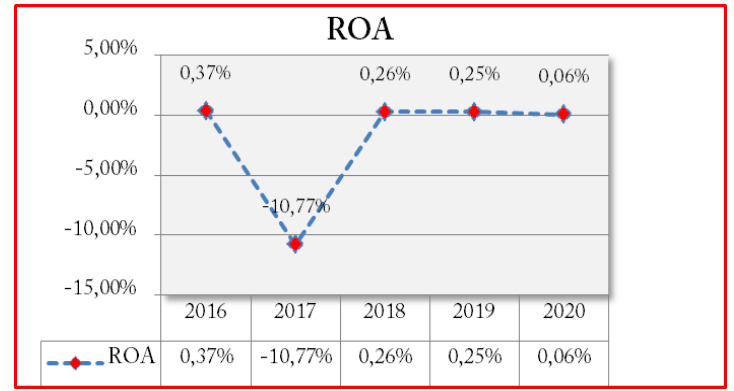

Gambar 4. ROA Bank Panin Dubai Syariah Tahun 2016-2020(Dalam Persen \%)

Sumber: Annual Report Panin Dubai Syariah

(2021)

Dilihat dari grafik diatas rasio Return on Asset (ROA) juga berfluktuasi setiap tahunnya namun terjadi penurunan secara ters menurus ditahun 2016 sampai dengan 2020 hal ini berarti semakin kecil Return on Asset (ROA) menunjukkan kinerja keuangan yang tidak baik atau tidak sehat. Dari tabel diatas pada tahun 2016 0.37\% tahun 2017 mengalami penurunan yang signifikan menjadi $-10.77 \%$ tahun 2018 0.26\% kemudian tahun 2019 mengalami penurunan menjadi $0.25 \%$ dan tahun 2020 juga kembali turun signifikan di angka $0.06 \%$. hal ini berarti semakin kecil Return on Asset (ROA) menunjukkan kinerja keuangan yang tidak baik atau tidak sehat.

\section{Hubungan NPF, FDR dengan ROA}

Analisis hubungan NPF, Financing dengan Return On Asset (ROA) pada Bank Panin Dubai Syariah Periode 20162020 (FDR) dengan Return on Asset 
(ROA) pada Bank Panin Dubai Syariah dilakukan ddengan Menggunakan SPSS Versi 26.0 Hasil Pengolahan Data Diperoleh Sebagai Berikut:

Tabel 5

Corelations

\begin{tabular}{|c|c|c|c|c|}
\hline \multicolumn{5}{|c|}{ Correlations } \\
\hline & & NPF & FDR & ROA \\
\hline \multirow{3}{*}{ NPF } & Pearson Correlation & 1 & ,949 &,$- 929^{\circ}$ \\
\hline & Sig. (2-tailed) & & .014 & ,022 \\
\hline & $\mathrm{N}$ & 5 & 5 & 5 \\
\hline \multirow[t]{3}{*}{ FDR } & Pearson Correlation & $949^{\circ}$ & 1 &,$- 930^{+}$ \\
\hline & Sig. (2-tailed) &, 014 & & ,022 \\
\hline & $\mathrm{N}$ & 5 & 5 & 5 \\
\hline \multirow[t]{3}{*}{ ROA } & Pears on Correlation &,$- 929^{\circ}$ &,$- 930^{\circ}$ & 1 \\
\hline & Sig. (2-tailed) &, 022 & ,022 & \\
\hline & $\mathrm{N}$ & 5 & 5 & 5 \\
\hline
\end{tabular}

*. Correlation is significant at the 0.05 level (2-tailed) Sumber: Pengolahan SPSS 26.0 (2021)

Analisis Hubungan Non Performing Financing (NPF) dengan Return on Asset (ROA)

Berdasarkan tabel diatas diperoleh koefisen korelasi atau $r=$ 0,929 dengan signifikansi sebesar 0,022 dengan taraf nyata nyata $(\alpha)$ sebesar $5 \%$. Nilai negatif korelasi menjelaskan bahwa apabila NPF naik maka ROA akan turun. Tingkat $r=-0,929$ menjelaskan tingkat hubungan antara NPF dengan ROA saling berhubungan dengan keratan hubungannya tinggi.

Dari hasil output menggunakan bantuan SPSS 26.0 dan pengujian hipotesis keduanya memberikan hasil bahwa NPF dan ROA pada Bank Panin Dubai Syariah memiliki hubungan apabila NPF mengalami kenaikan maka ROA mengalami penurunan dan sebaliknya.

NPF merupakan pinjaman yang mengalami kesulitan pembayaran atau kredit yang bermasalah. Masalah ini bisa disebutkan analisis kredit yang kurang tepat, kondisi ekonomi yang tidak stabil, hingga kegagalan yang terjadi pada kegiatan ekonomi. Rasio NPF dapat dijadikan sebagai indicator untuk mengidentifikasi kualitas pinjaman sebuah bank.

Non Performing Financing (NPF) merupakan cerminan dari besar atau kecilnya risiko pembiayaan yang dihadapi oleh lembaga keuangan syariah. Semakin tinggi NPF menunjukkan bahwa tidak kompeten atau profesionalnya lembaga keuangan dalam mengelola pembiayaannya.

Rendahnya kualitas kredit ini akan berdampat terhadap ROA, dimana profit yang diterima bank dari bagi hasil pembiayaan juga juga akan menurun.

Hasil penelitian ini sejalan dengan penelitian yang dilakukan oleh Fachri dan Mahfuz (2019) yang menunjukkan bahwa Non Performing Financing signifikan terhadap Return on Asset.

Alternatif yang bisa dilakukan untuk menekan angka NPF adalah denganadalah dengan membentuk organisasi manajemen asset, memberikan insentif pada bank, dan melakukan pendekatan kepada nasabah agar segera melakukan pembayaran hutang.

\section{Analisis Hubungan Financing Deposit Ratio (FDR) dengan Return on Asset (ROA)}

Berdasarkan tabel diatas diperoleh koefisen korelasi atau $r=-$ 0,930 dengan signifikansi sebesar 
0,022. Artinya FDR dan ROA memiliki hubungan negatif yang kuat dan signifikan dengan ROA, apabila FDR mengalami kenaikan maka ROA mengalami penurunan dan sebaliknya.

FDR merupakan seberapa besar dana pihak ketiga (DPK) Bank Syariah yang disalurkan untuk pembiayaan. Untuk mengatasi masalah tersebut maka apabila angka FDR terlalu tinggi, maka itu juga tidak baik untuk bank.

Semakin rendah FDR mengindikasikan bahwa kurang efektif bank dalam menyalurkan pembiayaan. Jika FDR sesuai dengan ketentuan BI, maka hal ini juga akan berdampak terhadap laba, karena penyaluran pembiayaan telah dilaksanakan secara efektif. Sehingga peningkatan laba ini juga akan berdampak terhadap peningkatan Return on Assetnya.

Penelitian ini sejalan dengan penelitian yang dilakukan oleh (Muhamad Faizal Fachri, 2021) yang menunjukkan bahwa FDR signifikan terhadap peningkatan ROA.

\section{PENUTUP}

Kesimpulan dari penelitian ini 1) Non Performing Financing memiliki hubungan negatif dan signifikan dengan ROA Artinya, apabila NPF mengalami kenaikan maka ROA akan mengalami penurunan dan sebaliknya. 2) Financing Deposit Ratio memiliki hubungan negatif dan signifikan dengan ROA Artinya, apabila NPF mengalami kenaikan maka ROA juga mengalami penurunan dan sebaliknya.

Berdasarkan kesimpulan diatas, maka ada beberapa saran yang dapat diberikan peneliti diantaranya adalah bagi Bank Panin Dubai Syariah untuk senantiasa menjaga Non Performing Financing (NPF) dan Financing Deposit Ratio yang sesuai dengan ketetapan minimal yang telah ditetapkan oleh Bank Indonesia agar mampu meningkatkan Retun on Asset dari Bank Panin Dubai Syariah

\section{DAFTAR KEPUSTAKAAN}

Akbar, T. (2019). Kajian Kinerja Profitabilitas Bank Pada Perspektif Bank Umum Berdasarkan Kegiatan Usaha. Ponorogo: Uwais Inspirasi Indonesia.

Leon, B, \& Ericson, S. (2007). Manajemen Aktiva Pasiva Bank Non Devisa. Jakarta: Grasindo.

Fahmi, I. (2015). Manajemen Perbankan Konvensional \& Syariah. Jakarta: Mitra Wacana Media.

Firdaus. (2021). Metodologi Penelitian Kuantitatif: Dilengkapi Analisis Regresi Ibm SPSS Statistics Version 26.0. Jakarta: Dotplus.

Hanafi. (2014). Manajemen Keuangan. Yogyakarta: BPFE UGM.

Jumingan. (2006). Analisis Laporan Keuangan. Jakarta: Bumi Aksara.

Kasmir. (2015). Manajemen Perbankan. Jakarta: RajaGrafindo Persada.

Kasmir. (2018). Analisis Laporan Keuangan. Jakarta: RajaGrafindo Persada.

Fachri, M. F, \& Mahfudz, M. (2021). Analisis Pengaruh CAR, BOPO, NPF dan FDR Terhadap ROA (Studi Pada Bank Umum Syariah Di Indonesia Periode Tahun 20162019). Journal Of Management, Vol. 10. No. 01. 2021. 
Wibisono, M, Y, \& Wahyuni, S. (2017).

Pengaruh CAR, NPF, BOPO, FDR, Terhadap ROA yang dimediasi Oleh NOM. Jurnal Bisnis Dan Manajemen, Vol. 17. No (01). 2017.

Niode, N.N, \& Chabachib, M, (2016). Pengaruh CAR, Pembiayaan, NPF, dan BOPO terhadap ROA Bank Umum Syariah Di Indonesia Periode 2010-2015. Diponegoro Journal Of Managemen, Vol. 5. No.3. 2016.

Prihadi, T. (N.D.). Analisis Rasio Keuangan. Jakarta: PPM.

Spomo, N. I. Dan B. (2002). Metodologi Penelitian Bisnis Untuk Akuntansi Dan Manajemen. Jakarta : Salemba Empat.

Sugiyono. (2016). Memahami Penelitian Kuantitatif, Kualitatif Dan $R \& D$. Bandung: Alfabeta.

Wangsawidjaja. (2020). Seri Pintar Perbankan Kredit Bank Umum Menurut Teori Dan Praktik Perbankan Indonesia. Jakarta: Lautan Pustaka. 